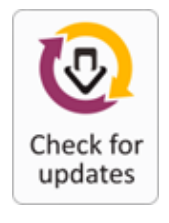

eck for undes

Article Type: Research Paper

\title{
AWARENESS AND KNOWLEDGE ASSESSMENT OF SUSTAINABLE DEVELOPMENT GOALS AMONG UNIVERSITY STUDENTS
}

\author{
Hafsah Fajar Jati ${ }^{1}$, Susilo Nur Aji Cokro Darsono ${ }^{1,4 *}$, Dedy Tri Hermawan ${ }^{1}$, \\ Wahdi April Salasi Yudhi ${ }^{2}$, and Ferry Fadzlul Rahman ${ }^{3}$
}

\section{OPEEN}

\section{AFFILIATION: \\ ${ }^{1}$ Universitas Muhammadiyah Yogyakarta, Yogyakarta, Indonesia. \\ 2 Sampoerna University, Jakarta, Indonesia \\ 3 Universitas Muhammadiyah Kalimantan Timur, Samarinda, Indonesia.}

${ }^{4}$ Asia University, Taichung, Taiwan.

\section{*CORRESPONDENCE:}

susilonuraji@umy.ac.id

\section{THIS ARTICLE IS AVALILABLE IN:}

http://journal.umy.ac.id/index.php/esp

DOI: $10.18196 /$ jesp.20.2.5022

\section{CITATION:}

Jati, H. F., Darsono, S. N. A. C., Hermawan, T., Yudhi, W. A. S., \& Rahman, F. F. (2019). Awareness and Knowledge Assessment of Sustainable Development Goals Among University Students. Jurnal Ekonomi \& Studi Pembangunan, 20(2), 163-175.

\section{ARTICLE HISTORY \\ Received:}

25 August 2019

\section{Accepted:}

25 October 2019

\begin{abstract}
The Sustainable Development Goals (SDGs) are built on the successes of the Millennium Development Goals (MDGs), which consists of 17 goals as a universal call to action to end poverty, protect the planet, and ensure that all people enjoy peace and prosperity. The assessment of people's awareness and knowledge on SDGs is of paramount importance to support any subsequent actions. The awareness of SDGs is higher compared to the previous agenda MDGs only in particular emerging countries; hence, it requires better progress after more than three years of its establishment. University students, as the agent of changes, are supposed to have a higher level of awareness and knowledge rather than average. When the university students have a better awareness and higher knowledge on SDGs, they can actively contribute to support, promote, and achieve the development goals by making use of their academic background. The objective of this research is to assess the level of awareness and knowledge on Sustainable Development Goals (SDGs) among university students in Universitas Muhammadiyah Yogyakarta, Indonesia. Data for this research are collected by field Survey and Questionnaire. This research analyzes data by using descriptive statistics and Chi-Square. The results show $89.5 \%$ of students are aware and $62.5 \%$ of students have high knowledge about SDGs. We found that students' knowledge is only affected by the accessibility of information and students' awareness is related to not only accessibility of information but also gender. Both awareness and knowledge are not affected by students' participation in the organization.
\end{abstract}

Keywords: Awareness; Knowledge; Sustainable Development Goals (SDGs); ChiSquare Analysis.

JEL Classification: 125

\section{Introduction}

Sustainable Development Goals (SDGs) or the 2030 Agenda for sustainable development initiated by the United Nations has been a global agenda for a better future. Awareness and knowledge regarding SDGs vary widely among people from different countries. Awareness means "knowing something exists and important" while knowledge is "the information, understanding and skills that you gain through education or experience" 
(Oxford Learner's Dictionaries). The level of society's awareness and knowledge of SDGs reflects whether they are aware or not, and how far they know general and particular information about SDGs; thus, they assign importance for themselves as well as government towards SDGs practices. The project of Sustainable Development Goals started since Millenium Development Goals (MDGs) ended in 2015 with some notable results: reduction in poverty, increase in primary education enrolment and gender parity, fall in child and global maternal mortality, and better access to sanitation. However, since some achievements have not met the initial target hence they are not ended yet and continued to the successor agenda - Sustainable Development Goals (SDGs) - with more substantial aspects compared to the previous one. The SDGs comprise 17 goals and 169 targets include ecological, social, and economic aspects. While MDGs were aimed mainly for developing countries for the sake of their advancement, SDGs would be infused to all states on this planet, either developing and developed countries.

United Nation's blueprint that craves better world by 2030 has set the 17 goals to pursue, (1) no poverty; (2) zero hunger; (3) good health and well-being; (4) quality education; (5) gender equality; (6) clean water and sanitation; (7) affordable and clean energy; (8) decent work and economic growth; (9) industry, innovation and infrastructure; (10) reduced inequalities; (11) sustainable cities and communities; (12) responsible consumption and production; (13) climate action; (14) life below water; (15) life on land; (16) peace, justice and strong institutions; (17) partnership for the goals. Although being compiled by that intricate goals and targets, the lane of sustainable development goals allows a common feature; the greater technological flexibility and less cost of actions that will be possible if policies implementation starts sooner.

Forming sustainable people and planet is attached to the educational system. Higher education therefore plays a significant role in facing the current agenda by giving education to the agent of change in university then giving birth to the well-educated graduates. Omisore, Babarinde, Bakare, and Asekun-Olarinmoye (2017) found in Osun State University, Southwestern Nigeria, only $43 \%$ of 450 students and staffs were aware of SDGs and $4.2 \%$ with good knowledge. Regarding this, the students' awareness and knowledge of 2030 Agenda are said as crucial issues for higher education. This study indicated a similar finding with the previous survey by Lampert \& Papadongonas (2016) that found only around $1 \%$ citizens who know the SDGs 'very well', while $25 \%$ say they know the name only. As this lack might suggest, to the contrary to firms or profit-oriented companies, sustainability reporting by universities is still in its infancy (Adams \& Petrella, 2010; Lopatta \& Jaeschke, 2014). This is also what has been a concern for research on sustainability reports disclosed by universities (Ceulemans, Molderez, \& Van Liedekerke, 2015).

However, a research conducted in University Libraries in Edo State found that most of the respondents had a high awareness due to the contribution of social media as an effective campaign tool (Ejechi, 2018). Similarly, people who are well-informed through personal study of the SDGs or other means or academic staff are those who have a good knowledge of SDGs. A survey for 171 respondents shows a total of 141 (82.46\%) were aware of SDGs and 140 (81.87\%) got the full meaning of SDGs correctly (Shehu, Shehu, \& Ode, 2018). The 
framework and roadmap carried in the SDGs can be integrated into a comprehensive area of initiatives, including pedagogy and learning, academic research, campus management, practices, and impact as an organization (Décamps, Barbat, Carteron, Hands, \& Parkes, 2017).

Awareness is "an understanding of the activities of others, which provides a context for your own activity" (Dourish \& Bellotti, 1992), The definition of awareness here is positioned upon the level of understanding. Furthermore, Gafoor (2012) defined awareness as "the state or ability to perceive, to feel, or to be conscious of events, objects, or sensory patterns" and it is indicated as the level of consciousness. De Quincey (2006) moreover seemed to fuse awareness with experience when talking about the light of consciousness being on. Being aware means to know, to realize or interested in knowing about something, or, to know that something is important. Awareness measurement has the object of what respondents know as well as what they do not know. It can either be tests of maximum performance or the tests of typical performance. In addition, it was pointed out that the foremost target of awareness should be to urge collaboration and particularly aspects of coordination, communication, and assistance (Gutwin and Greenberg, 2000).

Abhary, Andriansen, Begovac, Djukic, Qin, Spuzic, and Xing (2009) identified the knowledge processing as a key factor affecting social and economic sustainability, hence to understand the drawbacks of effective communication, sharing and use of knowledge are vital for the future of society. Majority theories defining the knowledge and explaining its nature have been integrated into two perspectives: rationalism and empiricism. Both theories accept that "knowledge is a justified true belief." Additionally, the main metaphors used for knowledge in the managerial literature are mentioned as follows: knowledge as objects, knowledge nuggets, knowledge as an iceberg, and knowledge as stocks and flows (Bolisani \& Bratianu, 2018).

Awareness and knowledge have been inflated to have the same essence in certain context. Despite some literatures have been vague to distinguish awareness and knowledge, we simplify the notion that awareness is more about personalization, perceiving, and self-focus, therefore depends on and directs to personal concerns to respond to something; while knowledge is attached to impersonal and factual nature, not only be true or correct but also justified (Hunt, 2003; Gafoor, 2012; Shaari, Ali, \& Ismail, 2015; Trevethan, 2017). The assessment of awareness of SDGs examines whether people have heard or not, how important to themselves, and what their stance and necessity for SDGs. While, knowledge is assessed to investigate their level of understanding regarding information related to SDGs.

In 2007 and 2016, 13 countries were surveyed for assessing public awareness of MDGs and SDGs respectively. It is found that that the awareness of SDGs is higher and the support is stronger compared to the previous agenda MDGs only in particular emerging countries such as India, Indonesia, and Kenya. The result of the 2016 survey was nearly three out of ten people (28\%) who said they have some or much awareness of the new goals, whereas in 2007 , on average, two out of ten people (20\%) claimed familiarity with 
the MDGs (GlobeScan, 2016). In accordance, AIESEC's Youth Speak Report (2016) stated that young people have a higher level of awareness than average towards SDGs. The assessment of both awareness and knowledge has been important to evaluate how far the global agenda has reached society and to know the progress after more than three years of its establishment. As the tagline "leave no one behind" created on SDGs, everyone is sure the participant in this project and that must be started by the good level of awareness and knowledge before going through some important actions and achieving the goals eventually.

Due to the vigor commitment and earlier actions made by the Indonesian government, Indonesia is one of the world's best examples of civil society, private sector, philanthropy and academic institutions actively embracing the SDGs. The Presidential Decree no 59/2017 as a regulation for Sustainable Development Goals to be implemented in Indonesia and it establishes the national governance structure as well as a distinct role to non-government actors (Bahuet \& Sopacua, 2018). Higher education systems like universities composed of lecturers, students, and staff set the supportive ground to promote the sustainable planet and people through an academic environment. The SDGs should be the substantial materials in universities setting particularly for students who act as the agent of changes. Therefore, this paper aims to assess the level of awareness and knowledge on Sustainable Development Goals (SDGs) among university students in Universitas Muhammadiyah Yogyakarta, Indonesia.

The rest of this paper is organized as follows. The second section describes the research methods used in this study. The third section presents the results followed by the discussion thereof. The final section is the conclusion.

\section{Research Method}

The data was collected by an online questionnaire, consisting of three major parts in addition to the basic information of the surveyed university students. The first part involves the student's knowledge of SDGs by using the multiple choices question of general information about SDGs. The second part was about the student's awareness of SDGs by using the Likert five-level measurement. The last part was made to check the accessibility of SDGs information in University students. The questionnaire was sent by mail to 450 students in the Faculty of Economics, Universitas Muhammadiyah Yogyakarta. The number of respondents was 203 (45.11\%), and three were discarded for incomplete information.

In this research, we firstly employ descriptive statistics to describe the characteristics of respondents. Then we conduct Chi-square analysis to investigate the effect among gender, participation in organization, and accessibility on the level of knowledge and awareness for the university students. In general, the Chi-square test determines the probability that two categorical variables are related. This research uses $p<0.05$ to reject the null hypothesis that the variables are independent. 


\section{Result and Discussion}

Two hundred one students were responded to this research. The table of descriptive statistics is shown in Table 1. There were 100 (50\%) male and 100 (50\%) female students. In this research, there were $118(59 \%)$ students who joined the organization in university and $82(41 \%)$ students did not join any organization in university. A total of 125 (62.5\%) had high knowledge of SDGs, while 75 (37.5\%) students had poor knowledge of SDGs. The university students were aware of SDGs for $89.5 \%$ (179 students), while $10.5 \%$ (21 students) were not aware of SDGs. There were 96 (48\%) students had high accessibility and 104 (52\%) students had low accessibility to the SDGs information.

The result of knowledge assessment about SDGs as shown in Table 2 was generally high, with $82.5 \%$ students answered correctly for the meaning of SDGs, $80.5 \%$ knew exactly how to achieved SDGs target, $72,5 \%$ students knew the amount of SDGs goals, $72 \%$ had correct answer on the name of previous development goals, $66 \%$ students had correct answer about the year for SDGs to be ended and $63 \%$ students knew who might be obliged to implement SDGs. While, there were three questions that had the wrong answer by $49 \%$ for the name of the organization that launched SDGs, 46.5\% for both SDGs 5P agenda and total targets in SDGs, and $42,5 \%$ for the question of the year when SDGs was launched. If the student was able to answer more than five questions correctly, it would be taken into account for the student to have high knowledge.

Table 1 Descriptive Statistics

\begin{tabular}{llll}
\hline Variable & & Frequency & Percentage (\%) \\
\hline Gender & Male & 100 & $50 \%$ \\
& Female & 100 & $50 \%$ \\
Participant in Organization & Organization & 118 & $59 \%$ \\
Knowledge about SDGs & Non-Organization & 82 & $41 \%$ \\
& High Knowledge & 125 & $62.5 \%$ \\
\hline Awareness on SDGs & Poor Knowledge & 75 & $37.5 \%$ \\
\hline \multirow{2}{*}{ Accessibility for SDGs Information } & Aware & 179 & $89.5 \%$ \\
& Not Aware & 21 & $10.5 \%$ \\
\hline & High Access & 96 & $48 \%$ \\
\hline
\end{tabular}

Table 2 Knowledge about SDGs

\begin{tabular}{lcc}
\hline Knowledge about SDGs & Correct (\%) & Wrong (\%) \\
\hline Meaning of SDGs & 82.5 & 17.5 \\
\hline The year it was launched & 57.5 & 42.5 \\
Name of previous development goals & 72 & 28 \\
\hline How many goals of SDGs & 72.5 & 27.5 \\
How many targets in SDGs & 53.5 & 46.5 \\
\hline P of SDGs Agenda & 53.5 & 46.5 \\
Name of Organization that launched SDGs & 51 & 49 \\
Who have obligation to implement SDGS & 63 & 37 \\
\hline The year it ended & 66 & 34 \\
\hline How to achieved SDGs target & 80.5 & 19.5 \\
\hline
\end{tabular}


Table 3 Accessibility of SDGs Information

\begin{tabular}{lcc} 
Accessibility of SDGs Information & Yes (\%) & No (\%) \\
\hline Know the SDGs Website & 38 & 62 \\
Read news about SDGs & 48.5 & 51.8 \\
Watch SDGs video & 40.5 & 59.5 \\
See the SDGs Campaign in Youtube\& Social Media & 54.5 & 45.5 \\
Have you ever heard the tagline of SDGs "Leave no one & 50 & 50 \\
behind" & & \\
\hline
\end{tabular}

Among all "knowledge" questions, the first question about what stands for the name "SDGs" got the most correct answer. More than seventy percent of students also knew that there was a previous agenda called Millenium Development Goals. However, many of them still did not know that SDGs was launched in 2015 and would end in 2030. Most students correctly answered that SDGs consist of 17 goals, but so many were mistaken in answering the number of targets, which is 169 targets. Agenda 2030 was made upon principles so-called " $5 \mathrm{P}$ " consisting of People, Planet, Prosperity, Peace, and Partnership. The question regarding 5P was answered incorrectly by almost half of the students. We asked them to choose which one among the options not included in the five Ps and only 107 students were unmistaken to answer Poverty. There were 98 students who did not know that the UN (United Nations) was the organization that launched the SDGs agenda, while this information must have been important and familiar. The majority chose that SDGs must be implemented by all society without exception and the way must be integrated mutually in order to reach the goals and targets.

Following the finding on the knowledge that the number of students with high knowledge was $25 \%$ higher than the ones with poor knowledge, the total students who were aware of SDGs exceeded those who were not aware, which is about 79 percent difference. The first question about awareness asked the students if they ever heard about Sustainable Development Goals and $21.9 \%$ answer referred to those who never heard it. But as university students, about $65.6 \%$ agreed to have a commitment at least to one goal and $61.2 \%$ were interested in SDGs, as was asked in the following questions. The majority of students were aware that Indonesia also took part in the implementation of SDGs; thus, it would be a responsibility to all of us and the Indonesian government should provide sufficient supports and political will to develop the country in achieving the Agenda 2030's targets.

Table 3 shows the accessibility of SDGs information among university students. Previously, Table 1 had informed the results of assessment consisted of low access for $52 \%$ (104 students) and 48\% (96 students) had high access to SDGs. This result is explained further in Table 3 and we found that $54.5 \%$ of the student mostly accessed SDGs information through the SDGs campaign on YouTube and other social media such as Instagram, Twitter, Facebook. Whereas, around $62 \%$ of students did not know the website of SDGs which provides full of information and recent data about sustainable development goals.

A series of Chi-squares analysis was conducted to explore the effects of gender, organization, and accessibility on student's knowledge about SDGs. As shown in Table 4, 
Table 4 The Chi-Square Analysis on Knowledge

\begin{tabular}{|c|c|c|c|c|c|c|c|}
\hline \multirow[t]{3}{*}{ Variable } & \multirow[t]{3}{*}{ Description } & \multirow[t]{3}{*}{ Category } & \multicolumn{4}{|c|}{ Knowledge } & \\
\hline & & & \multirow{2}{*}{\multicolumn{2}{|c|}{$\begin{array}{c}\text { Poor Knowledge } \\
\text { Frequency Percentage } \\
(\%)\end{array}$}} & \multicolumn{2}{|c|}{ High Knowledge } & \\
\hline & & & & & Frequency & $\begin{array}{c}\text { Percentage } \\
\text { (\%) }\end{array}$ & \\
\hline \multirow[t]{2}{*}{ Gender } & $\begin{array}{l}\text { Gender of } \\
\text { Student }\end{array}$ & Male & 43 & 21.5 & 57 & 28.5 & $X^{2}=2.581$ \\
\hline & & Female & 32 & 16 & 68 & 34 & $\begin{array}{c}\mathrm{P} \text { value }= \\
0.108\end{array}$ \\
\hline \multirow[t]{2}{*}{ Organization } & $\begin{array}{c}\text { Student } \\
\text { Participation } \\
\text { in } \\
\text { Organization }\end{array}$ & $\begin{array}{c}\text { Join } \\
\text { Organization }\end{array}$ & 41 & 20.5 & 77 & 38.5 & $X^{2}=0.932$ \\
\hline & & $\begin{array}{c}\text { Not Join } \\
\text { Organization }\end{array}$ & 34 & 17 & 48 & 24 & $\begin{array}{c}\mathrm{P} \text { value }= \\
0.334\end{array}$ \\
\hline \multirow[t]{2}{*}{ Accessibility } & $\begin{array}{c}\text { Accessibility o } \\
\text { SDGs } \\
\text { Information }\end{array}$ & High Access & 16 & 8 & 80 & 40 & $\begin{array}{c}X^{2}= \\
34.188\end{array}$ \\
\hline & & Low Access & 59 & 29.5 & 45 & 22.5 & $\begin{array}{c}P \text { value }= \\
0.001\end{array}$ \\
\hline
\end{tabular}

Source: SPSS data processing

the p-values of gender and organization were bigger than 0.05 ; it means that the knowledge of SDGs in students was not affected by their gender and their participation in an organization. While, the accessibility on SDGs information had an effect on knowledge of SDGs, with a p-value lower than 0.05 and $x 2=34.188$. The results from Table 4 demonstrated that the student who had high accessibility on SDGs information tended to gain a higher knowledge of SDGs.

The result in Table 5 shows the Chi-Square analysis to examine the effect of gender, organization, and accessibility on student's awareness in Sustainable Development Goals. There were two variables that have $p$-value lower than 0.05 , such as gender and accessibility, while the $p$-value of participation in an organization was 0.514 , higher than 0.05. Therefore, gender and accessibility had effects on the student's awareness of SDGs. Female students tended to be more aware, around $47.5 \%$ than the male students, $42 \%$. The students with high accessibility on SDGs information were around $47 \%$ aware on SDGs.

Over three years of the implementation of SDGs in Indonesia, this research found that the knowledge of SDGs in university students was good, with $62.5 \%$ of students had high knowledge. This is important because university student as an agent of change should have high knowledge of SDGs as their basic knowledge to develop the community and nation. While, based on the questions on knowledge about SDGs, we found that few students still lacked knowledge on basic information of SDGs such as the year it was launched, few agendas of SDGs and the organization which launched SDGs. However, the student knowledge result in this study is higher than the study from Shehu et al. (2018) among clinical medical students and Omisore et al. (2017) among University Community in Nigeria possibly because of the socio-demographic condition between the study area. 
Table 5 The Chi-Square Analysis on Awareness

\begin{tabular}{|c|c|c|c|c|c|c|c|}
\hline \multirow[t]{3}{*}{ Variable } & \multirow[t]{3}{*}{ Description } & \multirow[t]{3}{*}{ Category } & \multicolumn{4}{|c|}{ Awareness } & \\
\hline & & & \multicolumn{2}{|c|}{ Not Aware } & \multicolumn{2}{|c|}{ Aware } & \\
\hline & & & Frequency & $\begin{array}{c}\text { Percentage } \\
\text { (\%) }\end{array}$ & Frequency & $\begin{array}{l}\text { Percentage } \\
\text { (\%) }\end{array}$ & \\
\hline \multirow[t]{2}{*}{ Gender } & $\begin{array}{l}\text { Gender of } \\
\text { Student }\end{array}$ & Male & 16 & 8 & 84 & 42 & $\begin{array}{c}X^{2}= \\
6.438\end{array}$ \\
\hline & & Female & 5 & 2.5 & 95 & 47.5 & $\begin{array}{c}\mathrm{P} \text { value }= \\
0.011\end{array}$ \\
\hline \multirow[t]{2}{*}{ Organization } & $\begin{array}{c}\text { Student } \\
\text { Participation } \\
\text { in } \\
\text { Organization }\end{array}$ & $\begin{array}{c}\text { Join } \\
\text { Organization }\end{array}$ & 11 & 5.5 & 107 & 53.5 & $\begin{array}{c}X^{2}= \\
0.425\end{array}$ \\
\hline & & $\begin{array}{c}\text { Not Join } \\
\text { Organization }\end{array}$ & 10 & 5 & 72 & 36 & $\begin{array}{c}\mathrm{P} \text { value }= \\
0.514\end{array}$ \\
\hline \multirow[t]{2}{*}{ Accessibility } & $\begin{array}{l}\text { Accessibility } \\
\text { of SDGs } \\
\text { Information }\end{array}$ & High Access & 2 & 1 & 94 & 47 & $\begin{array}{c}X^{2}= \\
13.917\end{array}$ \\
\hline & & Low Access & 19 & 9.5 & 85 & 42 & $\begin{array}{c}\mathrm{P} \text { value }= \\
0.001\end{array}$ \\
\hline
\end{tabular}

Source: SPSS data processing

Further, the result of Chi-square analysis showed that gender and participation in an organization had no relationship with the knowledge on SDGs among the students. It was in line with goal number five in SDGs such as "Gender Equality", achieve gender equality and empower all women and girls. Female or women will increase their own family wellbeing when their education increases (Kabeer, 2010). Therefore, nowadays there are no problems regarding the process of gaining knowledge in university; all of the male and female students have the equal right to access the knowledge. The student participation in an organization also does not have a relationship with the knowledge on the SDGs. Students that have no participation in an organization might have high knowledge of SDGs. It happens because not all the organization in university specifically discusses and follows SDGs. While, the information of SDGs is available on many platforms, such as books, journals, websites, and many other social media. So, students without an organization can gain more than those who participated in an organization if they have a high spirit to do self-learning and develop their capability.

The accessibility of SDGs information had an effect on the student's knowledge, based on the Chi-Square analysis with $\mathrm{x} 2=34.188$ and $p$-value $<0.05$. Students who had high accessibility of information tended to gain higher knowledge of SDGs. In this disruptive era, we can access much information free, anywhere and anytime we need it. Most of the students in this study who are categorized as a millennial group are able to access the SDGs information through social media such as Instagram, Twitter, and YouTube for the visualize information. Nevertheless, most of the students are still lack access to the SDGs official website; it is not because they do not have any internet connection, but they prefer to gain information from the media which is used by them more often. Only, when they need the full information of SDGs, they will access the website. Promoting the accessibility of information is also one of the most significant commitment in SDGs, which is the concern of the goal number sixteen "Promote peaceful and inclusive communities for sustainable development, provide access to justice for all and build effective, 
accountable and inclusive institutions at all levels" (United Nations Development Group, 2015).

This research found that University students had awareness on Sustainable Development Goals with $89.5 \%$. This high level of awareness was a good condition for students to contribute to achieving SDGs. It is related to the survey from GlobeScan (2016) that showed the awareness of Indonesia on SDGs were higher than awareness on MDGs around $39 \%$ and $10 \%$, respectively. The effect of gender, participation in an organization, and accessibility of SDGs information on awareness were analyzed by Chi-Square. The result showed that participation in an organization did not have any relationship with the awareness of SDGs among the students. Similar to the result of knowledge of SDGs, students who do not participate in any organization might be aware since they can still receive information through media, especially the online ones. They might know the information from either formal classes or lectures, as well. This finding also implied that the study related to SDGs was not really emphasized through the activities of student organizations inside the campus.

Meanwhile, based on this research, gender had affected the awareness of students on SDGs slightly. It showed that female students had higher awareness such as $5.5 \%$ than male students. The previous studies by Shehu et al. (2018) and Omisore et al. (2017), differently, found with their female respondents being less aware of SDGs compared to the males. The different socio-demographic grounds and cultural expectations of gender roles might cause this inversed findings. Our finding that women whose higher awareness because it has been portrayed and substantiated stereotypically that women are more nurturing and empathetic, whereas men are less emotional and more cognitive (Christovmoore, Simpson, Coudé, Grigaityte, lacoboni, \& Ferrari, 2014). Awareness on SDGs includes both self and social awareness for which empathy is conflated inherently to understand and respond to the need of others. Studies in economics and medical also considered empathy's effect on decision making (Beadle, Paradiso, Kovach, Polgreen, Denburg, \& Tranel, 2012; Loewenstein, 2005).

The probability of independence between the accessibility to SDGs information with the level of awareness, as what we expected, was clearly rejected with the Chi-square test result. The accessibility of SDGs information affected the student's awareness of SDGs significantly with $\times 2=13.917$ and $p$-value $<0.05$. Students with a high level of accessibility tend to be more aware of SDGs. In other words, having time to find out about SDGs through social media, news, report, or course materials was associated significantly with the students to have more awareness. The higher access they get, the better awareness they have. Furthermore, a condition of being aware of SDGs will consequently help the students to have better knowledge afterward.

This research has found that the accessibility of SDGs information significantly affected the level of both knowledge and awareness among university students. The main idea for this finding can be stated that accessible information of SDGs is a crucial driving force behind the implementation of what is designed in sustainable development goals and targets. Students who already received any form of enlighentment on SDGs would own a 
bigger chance as well as responsibility to support their societies or at least to start improving from themselves. In this research, we found that more than half of the respondents have access to SDGs information because they see the campaign on YouTube or any social media platforms. These online instruments, in any case, are more affordable, reachable, and also preferable for the young generation to seek worldwide issues. It is, therefore indisputable to say that campaign and promotion through online media have been playing a big role in bringing students' knowledge and awareness forward.

Students' participation in an organization, however, has been found to be insignificant to both knowledge and awareness level. The results tell that not participating in an organization did not yield to the condition of being a lack of global issues. Nevertheless, it could not be translated right away that joining the organization on the campus is less useful to build up awareness and knowledge, inasmuch as the point here is the student's individual effort and willingness to be open-minded to what is going on now in the world. Moreover, it invites a suggestion for campus organizations to start adopting and adjusting their own goals to the framework of sustainable development goals or any other global issues. It is compulsory to relate these goals with organizational patterns and challenges since it is what has been expected from the inevitable adjustment of the disruptive era. Further, those who belong to university students' associations are said to be in an advantageous position since they are the representatives of university students as a whole. They are taking the special role of the agent of changes within organizational structures in which attitudes and actions are the outcomes of good awareness and knowledge. In addition, both awareness and knowledge are supposed to be attainable by students from any organizational backgrounds as well as those who do not belong to any, since what is expected from the 6th target of the goal number four that it should "ensure that all youth and a substantial proportion of adults, both men and women, achieve literacy and numeracy."

Unlike student's participation in organization and accessibility to information that give unchanging effect towards both knowledge and awareness of SDGs, gender has a different relationship with knowledge and awareness. Based on Chi-square analysis, gender does affect awareness significantly yet does not have any influences on the level of knowledge. Female students are more aware than male students, however, both are able to attain the indifferent knowledge regardless of their gender. This is explicable in terms of defining the level of awareness and knowledge differently. We have mentioned awareness with its position as the level of understanding and consciousness (Dourish \& Bellotti, 1992; Gafoor, 2012). While, knowledge is on the upper level or stronger position; not only being aware but also having more cognition, deliberately, and well-informed. Many studies in ethology, social psychology, economics, and neuroscience have been investigating the relationship between gender, brain, and behavior. Christov-moore et al. (2014) asserted that females exhibit higher rates than males in various rudimentary forms of empathy, including social referencing, general social interest, and sensitivity. On the other hand, males appear to show more utilitarian behavior as well as greater recruitment of areas involved in cognitive control and cognition. In brief, women tend to have more emotional empathy, while men's are cognitive empathy. Cognitive empathy activates areas involved in language and processing of semantic content, meaning stronger than 
emotional empathy does (Nummenmaa, Hirvonen, Parkkola, \& Hietanen 2008; Benelli et al., 2012; and Thomas, 2013).

\section{Conclusion}

Sustainable Development Goals (SDGs), also known as Agenda 2030, strive to form sustainable people and planet, and the implementation needs to be started first from the educational system that has a crucial role in educating students as the agent of changes among society. The assessments of awareness and knowledge about Sustainable Development Goals among university students are analyzed by using questionnaires regarding the information about SDGs to collect the answers from students and measure how many questions are solved correctly. This research examines the number of students at Universitas Muhammadiyah Yogyakarta who are aware and not aware about SDGs and who have high and poor knowledge of SDGs and then make group of them based on gender, participation in organization, and accessibility of SDGs information to analyze whether or not those have relationship with students' awareness and knowledge on SDGs.

The finding shows that students' awareness and knowledge at the Faculty of Economics and Business, Universitas Muhammadiyah Yogyakarta, are good because more than half of the total students engaged in this research are aware and have high knowledge about SDGs matters. From 200 students, $89.5 \%$ of students have an awareness and $62.5 \%$ of students have high knowledge about the Sustainable Development Goals agenda. These results lead to the inference that students in Universitas Muhammadiyah Yogyakarta are the good agent of changes for implementing awareness and knowledge of SDGs in a broader community and also encouraging society to take part in succeeding 2030 Agenda. This research also figures out several variables that affect students' awareness and knowledge of SDGs. Firstly, gender affects students' awareness since it is found that females are more aware of SDGs rather than males, however, it has no effects on their knowledge concerning Sustainable Development Goals. Secondly, accessibility to SDGs' information significantly affects both awareness and knowledge. Students whose high access tend to be more aware and have high knowledge of SDGs. Lastly, participation in students organization, on the other hand, does not have a relationship with awareness nor knowledge on SDGs since some students could be enlightened by the SDGs contents as long as they are willing to do self-learning and develop new insight from worldwide issues. These results are important to reassert students' positions, status, and roles in contributing themselves to SDGs enforcement.

After all, there are several limitations. In this current research, the assessment is made based upon students' awareness and knowledge only for Sustainable Development Goals in terms of general information about that agenda. It does not include the more specific and itemized assessment for each goal andtarget in SDGs or which targets have more urgency and influential to the realm of university students. Considering detailed aspects to be assessed and to put in the research would be superior in resulting loaded findings. This could be a takeaway for future studies. Due to the limitation of methodology, this 
research is only able to determine the probability that the two variables are related by using the Chi-square test, but unable to tell their interaction in more detail. Another matter is the limited sample size of this research. It is suggested to widen the sample size for further studies.

\section{References}

Abhary, K., Andriansen, H. K., Begovac, F., Djukic, D., Qin, B., Spuzic, S., \& Xing, K. (2009). Some Aspects of Defining Knowledge. Retrieved April 3, 2019, from http://epistemic.synthasite.com/

Adams, C., \& Petrella, L. (2010). Collaboration, Connections and Change. Sustainability Accounting, Management and Policy Journal, 1(2), 292-296. http://doi.org/10.1108/20408021011089284

AIESEC. (2016). Youth Speak Global Report 2016. AIESEC Website. https://issuu.com/aiesecinternational/docs/report youthspeak 2016

Bahuet, C., \&Sopacua, J. A. (2018). SDGs in Indonesia: 2018 and Beyond. Retrieved April 3, 2019, from http://www.id.undp.org/content/indonesia/en/home/presscenter/articles/2018/sd gs-in-indonesia--2018-and-beyond.html

Beadle, J. N., Paradiso, S., Kovach, C., Polgreen, L., Denburg, N. L., \& Tranel, D. (2012). Effects of Age-Related Differences in Empathy on Social Economic DecisionMaking, 822-833. http://doi.org/10.1017/S1041610211002547

Benelli, E., Mergenthaler, E., Walter, S., Messina, I., Sambin, M., Buchheim, A., Viviani, R. (2012). Emotional and Cognitive Processing of Narratives and Individual Appraisal Styles: Recruitment of Cognitive Control Networks Vs. Modulation of Deactivations. Frontiers in Human Neuroscience, 6(May). http:/ / doi.org/10.3389/fnhum.2012.00239

Bolisani, E., \& Bratianu, C. (2018). Chapter 1 The Elusive Definition of Knowledge. http://doi.org/10.1007/978-3-319-60656

Ceulemans, K., Molderez, I., \& Van Liedekerke, L. (2015). Sustainability Reporting in Higher Education: A Comprehensive Review of the Recent Literature and Paths for Further Research. Journal of Cleaner Production, 106, 127-143. http://doi.org/10.1016/j.jclepro.2014.09.052

Christov-Moore, L., Simpson, E. A., Coudé, G., Grigaityte, K., Iacoboni, M., \& Ferrari, P. F. (2014). Empathy: Gender Effects in Brain and Behavior. Neurosci Biobehav Review, 46(4), 604-627. https://doi.org/10.1016/i.neubiorev.2014.09.001

De Quincey, T. (2006). The Works of Thomas De Quincey: The Confessions of an English Opium Eater; The Daughter of Lebanon, Volume 1. United State: Kessinger Publishing.

Décamps, A., Barbat, G., Carteron, J. C., Hands, V., \& Parkes, C. (2017). Sulitest: A Collaborative Initiative to Support and Assess Sustainability Literacy in Higher Education. International Journal of Management Education, 15(2), 138-152. http://doi.org/10.1016/j.ijme.2017.02.006

Dictionaries, O. L. (n.d.). Definition of Awareness Noun from the Oxford Advanced Learner's Dictionary. Retrieved April 3, 2019, from https://www.oxfordlearnersdictionaries.com/definition/english/awareness?q=aware ness

Dictionaries, O. L. (n.d.). Definition of Knowledge Noun from the Oxford Advanced Learner's Dictionary. Retrieved April 3, 2019, from https://www.oxfordlearnersdictionaries.com/definition/english/knowledge?q=knowl 
$\underline{\text { edge }}$

Dourish, P., \& Bellotti, V. (1992). Awareness and Coordination in Shared Workspaces. In CSCW 92 Proceedings (pp. 107-114). https://doi.org/10.1145/143457.143468

Ejechi, V. (2018). Awareness and Perception of Sustainable Development Goals (SDGs), among, Library Personnel in Edo state University Library, (February). https://www.researchgate.net/publication/323391987

Gafoor, K. A. (2012). Considerations in Measurement of Awareness National Seminar on Emerging Trends in Education, (November), 1-6. https:// files.eric.ed.gov/fulltext/ED545374.pdf

GlobeScan. (2016). Awareness of Sustainable Development Goals ( SDGs) vs Millennium Development Goals (MDGs). https://globescan.com/awareness-of-sustainable-development-goalssdgs-vs-millennium-development-goals-mdgs/

Gutwin, C., \& Greenberg, S. (2000). The Effects of Workspace Awareness Support on the Usability of Real-Time Distributed Groupware, 6(3), 243-281. https://doi.org/10.1145/329693.329696

Hunt, D. P. (2003). The Concept of Knowledge and How to Measure it. Journal of Intellectual Capital, 4(1), 100-113. https://doi.org/10.1108/14691930310455414

Kabeer, N. (2010). Gender Equality and Women's Empowerment: A Critical Analysis of the Third Millennium Development Goal 1. Gender \& Development, 13(1), 13-24. https://doi.org/10.1080/13552070512331332273

Lampert, M., \& Papadongonas, P. (2016). Glocalities: Towards 2030 without Poverty. https://utvecklingsarkivet.se/wp-content/uploads/2011/03/Towards-2030-withoutpoverty-Glocalities2016.pdf

Loewenstein, G. (2005). Hot - Cold Empathy Gaps and Medical Decision Making, 24(4), 49-56. http://doi.org/10.1037/0278-6133.24.4.S49

Lopatta, K., \&Jaeschke, R. (2014). Sustainability Reporting at German and Austrian Universities Kerstin Lopatta * and ReemdaJaeschke, 5(1), 66-90. https://doi.org/10.1504/IJEED.2014.059868

Nummenmaa, L., Hirvonen, J., Parkkola, R., \& Hietanen, J. K. (2008). Is Emotional Contagion Special? An fMRI Study on Neural Systems for Affective and Cognitive Empathy. NeuroImage, 43(3), 571-580. http://doi.org/10.1016/j.neuroimage.2008.08.014

Omisore, A. G., Babarinde, G. M., Bakare, D. P., \& Asekun-Olarinmoye, E. O. (2017). Awareness and Knowledge of the Sustainable Development Goals in a University Community in Southwestern Nigeria. Ethiopian Journal of Health Sciences, 27(6), 669. http://doi.org/10.4314/ejhs.v27i6.12

Shaari, N., Ali, A., \& Ismail, N. (2015). Student's Awareness and Knowledge on the Implementation of Goods and Services Tax (GST) in Malaysia. Procedia Economics and Finance, 31(15), 269-279. https://doi.org/10.1016/s2212-5671(15)01229-0

Shehu, M., Shehu, H., \& Ode, M. B. (2018). Pattern of Smartphone Use Among Clinical Medical Students of Bingham University Teaching Hospital, Jos. Central African Journal of Public Health, 4, (5), 137-142. https://doi.org/10.11648/j.caiph.20180405.12

Trevethan, R. (2017). Deconstructing and Assessing Knowledge and Awareness in Public Health Research. Frontiers in Public Health, 5(August), 16-19. https://doi.org/10.3389/fpubh.2017.00194 